\title{
Assessment of Computed Tomography (CT) And Magnetic Resonance Imaging (MRI) Based Radiosurgery Treatment Planning for Pituitary Adenomas
}

\author{
Selcuk Demiral*, Omer Sager, Ferrat Dincoglan and Murat Beyzadeoglu \\ Department of Radiation Oncology, University of Health Sciences, Turkey
}

Submission: February 08, 2019; Published: March 14, 2019

"Correspondence Author: Selcuk Demiral, University of Health Sciences, Gulhane Medical Faculty, Department of Radiation Oncology, Gn Tevfik Saglam Cad. 06018, Etlik, Kecioren, Turkey

\begin{abstract}
Aim: Pituitary adenomas are fairly common benign tumors which may be found in up to $20 \%$ of the general population. While a considerable proportion of patients harboring these benign tumors may be asymptomatic, symptoms may arise due to the mass effect on critical neurovascular structures including the optic nerves and chiasm, cavernous sinus, and normally functioning pituitary gland or stalk. Radiosurgery may be used as a viable therapeutic option for management of pituitary adenomas. Treatment planing for radiosurgery is typically performed by Computed Tomography (CT)-simulation, however, multimodality imaging may add to the accuracy of target contouring for pituitary adenomas. In this study, we evaluated the utility of multimodality imaging with CT and Magnetic Resonance Imaging (MRI) for radiosurgery treatment planning of pituitary adenomas.
\end{abstract}

Methods and Materials: The study group included 18 patients who received radiosurgery for pituitary adenoma at our department. A comparative assessment was performed to investigate the incorporation of MRI into radiosurgery treatment planning for pituitary adenomas.

Results: A total of 18 patients receiving radiosurgery for pituitary adenomas at our department were assessed for target volume definition by use of CT-only imaging and CT-MR fusion based imaging in this study. Mean target volume was $4.4 \mathrm{cc}$ (range: 1.1-10.9 cc) on CT-only imaging, $4.7 \mathrm{cc}$ (range: 1.2-11.1 cc) on CT-MR fusion based imaging, and $4.6 \mathrm{cc}$ (range: 1.2-11.2 cc) on collaboration and consensus of treating radiation oncologists by using all available imaging data of the patients.

Conclusion: Ground truth target volume was identical to target determination based on CT-MR fusion based imaging in majority of our study group. MRI offers a viable imaging modality for pituitary adenoma target definition and may substantially improve accuracy and precision in target contouring for radiosurgery of pituitary adenomas.

Keywords: Pituitary adenoma; Stereotactic Radiosurgery (SRS); Fractionated Stereotactic Radiotherapy (FSRT); Hypofractionated Stereotactic Radiotherapy (HFSRT); Target definition; Computed Tomography (CT); Magnetic Resonance Imaging (MRI)

\section{Introduction}

Pituitary adenomas are fairly common benign tumors which may be found in up to $20 \%$ of the general population [1-3]. Categorization of pituitary adenomasis typically performed based on lesion size (microadenomas or macroadenomas) and hormon secretion status (functioning or nonfunctioning adenomas). While a considerable proportion of patients harboring these benign tumors may be asymptomatic, symptoms may arise due to the mass effect on critical neurovascular structures including the optic nerves and chiasm, cavernous sinus, and normally functioning pituitary gland or stalk. Occurring symptoms may profoundly deteriorate the affected patients' health status and quality of life, and prompt management may be considered. Medical treatment, surgery, and radiation therapy (RT) are among the therapeutic options for management of pituitary adenomas. Surgery is a primary mode of treatment for pituitary adenomas, however, some lesions may not be amenable to complete surgical removal due to their intimate association with vital neurovascular structures. From this aspect, RT may be considered as an alternative or complementary treatment modality utilized after partial surgical removal of pituitary adenomas. Another typical utilization of RT is for management of recurrences which may occur in a considerable proportion of patients even after successful initial management. 


\section{Cancer Therapy \& Oncology International Journal}

Radiosurgery in the form of Stereotactic Radiosurgery (SRS), Fractionated Stereotactic Radiation Therapy (FSRT), Hypofractionated Stereotactic Radiation Therapy (HFSRT), and Stereotactic Body Radiation Therapy (SBRT) has been judiciously utilized for management of several benign and malign conditions throughout the human body with encouraging therapeutic outcomes [4-22]. For management of pituitary adenomas, several studies reported the safety and efficacy of radiosurgery $[8,23,24]$. Due to the critical location of pituitary adenomas in close vicinity of several vital structures, achieving a favorable toxicity profile is a pertinent goal of RT as well as surgery. Treatment planing for radiosurgery is typically performed by Computed Tomography (CT)-simulation, however, multimodality imaging may add to the accuracy of target contouring for pituitary adenomas. In this study, we evaluated the utility of multimodality imaging with CT and Magnetic Resonance Imaging (MRI) for radiosurgery treatment planning of pituitary adenomas.

\section{Materials and Methods}

The study group included 18 patients who received radiosurgery for pituitary adenoma at our department. Written informed consent was provided for each patient before radiosurgical treatment. Decision making for radiosurgery was performed after thorough patient assessment by a multidisciplinary team of experts on neurosurgery, radiation oncology, and neuroradiology. Factors such as lesion size, location and association with critical structures, patient symptomatology, age, performance status and preferences were considered. All patients had thin slice MRI typically acquired within one week before radiosurgery. On treatment day, immobilization was secured by use of a stereotactic head frame which was affixed to the patients' skull under local anesthesia with 4 pins. Patients underwent CT-simulation at the CT-simulator (GE Lightspeed RT, GE Healthcare, Chalfont St. Giles, UK) at our department. Planning CT images were sent to the contouring workstation (SimMD, GE, UK) for delineation of the target and neighbouring critical structures such as the brainstem, optic nerves, optic chiasm, pituitary stalk, and pituitary gland. Target delineation was based on CT-simulation images only or fused CT and T1 gadolinium-enhanced MR images. A comparative assessment was performed to investigate the incorporation of MRI into radiosurgery treatment planning for pituitary adenomas. For actual treatment and comparison purposes, the ground truth target volume was generated after collaboration and consensus of treating radiation oncologists by using all available imaging data of the patients.

\section{Results}

A total of 18 patients receiving radiosurgery for pituitary adenomas at our department were assessed for target volume definition by use of CT-only imaging and CT-MR fusion based imaging in this study. Mean target volume was $4.4 \mathrm{cc}$ (range:
1.1-10.9 cc) on CT-only imaging, 4.7 cc (range: 1.2-11.1 cc) on CT-MR fusion based imaging, and $4.6 \mathrm{cc}$ (range: 1.2-11.2 cc) on collaboration and consensus of treating radiation oncologists by using all available imaging data of the patients. Ground truth target volume was identical to target determination based on CTMR fusion based imaging in majority of the study group. Target volume delineation was optimized by adjustment of appropriate windows and levels for radiosurgery treatment planning. In treatment planning for radiosurgery, either a single 360-degree, double 360-degree arcs or five 180-degree arcs were used for optial sparing of critical structures surrounding the target. Arc Modulation Optimization Algorithm (AMOA) was utilized for achieving optimal target coverage and normal tissue sparing. Radiosurgery treatment planning was accomplished by use of ERGO ++ (CMS, Elekta, UK) radiosurgery planning system and treatment delivery was performed by using Synergy (Elekta, UK) Linear Accelerator (LINAC) with 6-MV photons. Median dose of radiosurgery was 13 Gy (range: 10-16 Gy) prescribed to the $85 \%-95 \%$ isodose line encompassing the target. Isocenter and setup verifications were performed by use of kV-CBCT (kilovoltage Cone Beam CT) and XVI (Xray Volumetric Imaging, Elekta, UK) system integrated into the LINAC gantry. All patients routinely received $8 \mathrm{mg}$ intravenous dexamethasone with $\mathrm{H} 2$ antihistamines after radiosurgical treatment (Figure 1).

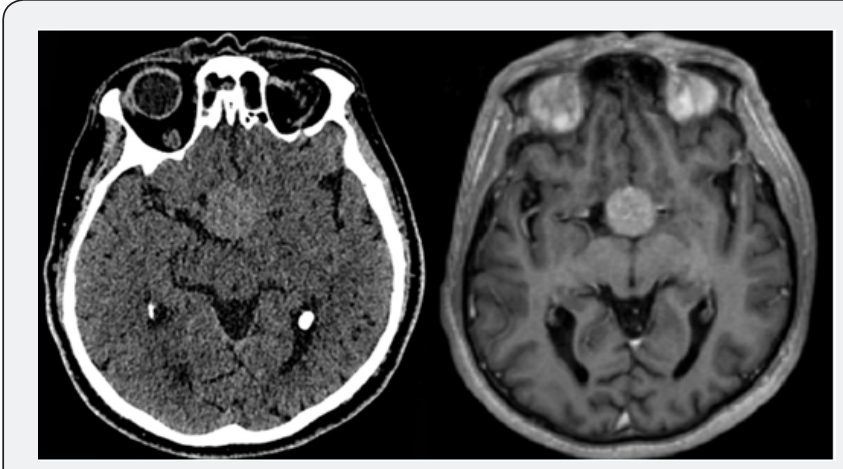

Figure 1: Treatment planning CT and MR images of a patient with pituitary adenoma.

\section{Discussion}

Pituitary adenomas may cause several symptoms depending on their location and association with surrounding critical structures. Therapeutic options for management typically include medical treatment, surgery, and RT. Management with complete surgical resection may be hampered due to the excessive risk of surgical complications particularly when the pituitary adenoma lesion is in close contact with the optic apparatus or vital neurovascular structures located in the cavernous sinus. RT offers a viable treatment modality and may be utilized for complementary or definitive management of pituitary adenomas in selected patients. Conventionally fractionated RT has been traditionally used for treatment of pituitary adenomas, however, radiosurgery in the form of SRS or HFSRT has emerged as a viable radiotherapeutic modality for management of well- 


\section{Cancer Therapy \& Oncology International Journal}

defined lesions with small to moderate size. Primary advantage of radiosurgery is management of patients with a condensed treatment schedule by use of one or a few fractions while achieving steep dose gradients around the target resulting in optimal normal tissue sparing. Nevertheless, excessive toxicity is an important concern for management of pituitary adenomas with radiosurgery a well as surgical resection and achieving an improved toxicity profile is a pertinent goal of irradiation as well to avoid adverse radiation effects $[25,26]$. In this context, several strategies have been implemented for avoiding excessive treatment toxicity such as deferral of irradiation, proton therapy, and combined modality management including surgery followed by SRS [27-32].

An important aspect of precision radiosurgery is accurate definition of the target given the high fractional doses and steep dose gradients around the target in radiosurgical treatments. There may be interobserver variability in delineation of the target and critical structures which may lead to inadequate treatment and unexpected toxicity, emphasizing the need for vigilance in contouring of the pituitary adenoma target and relevant critical structures for achieving optimal radiosurgical outcomes [33-35]. While CT-simulation is a common practice for radiosurgery, incorporation of MRI may add to the accuracy of target definition. In our study, ground truth target volume was identical to target determination based on CT-MR fusion based imaging in majority of the patients. Our study supports the incorporation of MRI into radiosurgery target definition for improving the accuracy of treatment. In conclusion, MRI offers a viable imaging modality for pituitary adenoma target definition and may substantially improve accuracy and precision in target contouring for radiosurgery of pituitary adenomas.

\section{Conflicts Interest}

There are no conflicts of interest and no acknowledgements.

\section{References}

1. Laws ER Jr, Vance ML (1999) Radiosurgery for pituitary tumors and craniopharyngiomas. Neurosurg Clin N Am 10(2): 327-336.

2. Jagannathan J, Kanter AS, Sheehan JP, Jane JA Jr, Laws ER Jr (2007) Benign brain tumors: sellar/parasellar tumors. Neurol Clin 25(4): 1231-1249.

3. Dekkers OM, Pereira AM, Romijn JA (2008) Treatment and follow-up of clinically non-functioning pituitary macroadenomas. J Clin Endocrinol Metab 93(10): 3717-3126.

4. Sirin S, Oysul K, Surenkok S, Sager O, Dincoglan F, et al. (2011) Linear accelerator-based stereotactic radiosurgery in recurrent glioblastoma: A single center experience. Vojnosanit Pregl 68(11): 961-966.

5. Dincoglan F, Sager O, Gamsiz H, Demiral S, Uysal B, et al. (2012) Management of arteriovenous malformations by stereotactic radiosurgery: A single center experience. Int J Hematol Oncol 22: 107112.

6. Dincoglan F, Beyzadeoglu M, Sager O, Oysul K, Sirin S, et al. (2012) Image-guided positioning in intracranial non-invasive stereotactic radiosurgery for the treatment of brain metastasis. Tumori 98(5): 630-635.

7. Dincoglan F, Sager O, Gamsiz H, Uysal B, Demiral S, et al. (2012) Stereotactic radiosurgery for intracranial tumors: A single center experience. Gulhane Med J 54: 190-198.

8. Surenkok S, Sager O, Dincoglan F, Gamsiz H, Demiral S, et al. (2012) Stereotactic radiosurgery in pituitary adenomas: a single center experience. Int J Hematol Oncol 22: 255-260.

9. Demiral S, Beyzadeoglu M, Uysal B, Oysul K, Kahya YE, et al. (2013) Evaluation of stereotactic body radiotherapy (SBRT) boost in the management of endometrial cancer. Neoplasma 60(3): 322-327.

10. Sager O, Beyzadeoglu M, Dincoglan F, Demiral S, Uysal B, et al. (2013) Management of vestibular schwannomas with linear acceleratorbased stereotactic radiosurgery: A single center experience. Tumori 99(5): 617-622.

11. Dincoglan F, Beyzadeoglu M, Sager O, Uysal B, Demiral S, et al. (2013) Evaluation of linear accelerator-based stereotactic radiosurgery in the management of meningiomas: A single center experience. J BUON 18(3): 717-722.

12. Gamsiz H, Beyzadeoglu M, Sager O, Dincoglan F, Demiral S, et al. (2014) Management of pulmonary oligometastases by stereotactic body radiotherapy. Tumori 100(2): 179-183.

13. Sager O, Beyzadeoglu M, Dincoglan F, Gamsiz H, Demiral S, et al. (2014) Evaluation of linear accelerator-based stereotactic radiosurgery in the management of glomus jugulare tumors. Tumori 100(2): 184-188.

14. Sager O, Beyzadeoglu M, Dincoglan F, Uysal B, Gamsiz H, et al. (2014) Evaluation of linear accelerator (LINAC)-based stereotactic radiosurgery (SRS) for cerebral cavernous malformations: A 15-year single-center experience. Ann Saudi Med 34(1): 54-58.

15. Demiral S, Beyzadeoglu M, Sager O, Dincoglan F, Gamsiz H, et al. (2014) Evaluation of linear accelerator (linac)-based stereotactic radiosurgery (srs) for the treatment of craniopharyngiomas. Int J Hematol Oncol 24(2): 123-129.

16. Dincoglan F, Sager O, Gamsiz H, Uysal B, Demiral S, et al. (2014) Management of patients with $\geq 4$ brain metastases using stereotactic radiosurgery boost after whole brain irradiation. Tumori 100(3): 302 306.

17. Sager O, Dincoglan F, Beyzadeoglu M (2015) Stereotactic radiosurgery of glomus jugulare tumors: Current concepts, recent advances and future perspectives. CNS Oncol 4(2): 105-114.

18. Dincoglan F, Beyzadeoglu M, Sager O, Demiral S, Gamsiz H, et al (2015) Management of patients with recurrent glioblastoma using hypofractionated stereotactic radiotherapy. Tumori 101(2): 179-184.

19. Gamsiz H, Beyzadeoglu M, Sager O, Demiral S, Dincoglan F, et al. (2015) Evaluation of stereotactic body radiation therapy in the management of adrenal metastases from non-small cell lung cancer. Tumori 101(1): 98-103.

20. Demiral S, Dincoglan F, Sager O, Gamsiz H, Uysal B, et al. (2016) Hypofractionated stereotactic radiotherapy (HFSRT) for who grade 1 anterior clinoid meningiomas (ACM). Jpn J Radiol 34(11): 730-737.

21. Dincoglan F, Sager O, Demiral S, Uysal B, Gamsiz H, et al. (2017) Radiosurgery for recurrent glioblastoma: a review article. Neurol Disord Therap 1(4): 1-5.

22. Demiral S, Dincoglan F, Sager O, Uysal B, Gamsiz H, et al. (2018) Contemporary Management of Meningiomas with Radiosurgery. Int Radiol Imaging Technol 4(2): 041. 


\section{Cancer Therapy \& Oncology International Journal}

23. Minniti G, Flickinger J, Tolu B, Paolini S (2018) Management of nonfunctioning pituitary tumors: radiotherapy. Pituitary 21(2): 154161.

24. Narayan V, Mohammed N, Bir SC, Savardekar AR, Patra DP, et al (2018) Long-Term Outcome of Nonfunctioning and Hormonal Active Pituitary Adenoma After Gamma Knife Radiosurgery. World Neurosurg 114: e824-e832.

25. Tooze A, Sheehan JP (2018) Neurocognitive changes in pituitary adenoma patients after Gamma Knife radiosurgery. J Neurosurg 129(Suppl1): 55-62.

26. Graffeo CS, Link MJ, Brown PD, Young WF Jr, Pollock BE (2018) Hypopituitarism After Single-Fraction Pituitary Adenoma Radiosurgery: Dosimetric Analysis Based on Patients Treated Using Contemporary Techniques. Int J Radiat Oncol Biol Phys 101(3): 618623

27. Nicholas SE, Salvatori R, Quinones-Hinojosa A, Redmond K, Gallia G, et al. (2019) Deferred Radiotherapy After Debulking of Non-functioning Pituitary Macroadenomas: Clinical Outcomes. Front Oncol 8: 660.

28. Pomeraniec IJ, Dallapiazza RF, Xu Z, Jane JA Jr, Sheehan JP (2016) Early versus late Gamma Knife radiosurgery following transsphenoidal resection for nonfunctioning pituitary macroadenomas: a matched cohort study. J Neurosurg 125(1): 202-212.

29. Pomeraniec IJ, Kano H, Xu Z, Nguyen B, Siddiqui ZA, et al. (2018) Early versus late Gamma Knife radiosurgery following transsphenoidal surgery for non-functioning pituitary macroadenomas: a multicenter matched-cohort study. J Neurosurg 129(3): 648-657.

30. Lesueur P, Calugaru V, Nauraye C, Stefan D, Cao K, et al. (2019) Proton therapy for treatment of intracranial benign tumors in adults: A systematic review. Cancer Treat Rev 72: 56-64.

31. Kim EH, Oh MC, Chang JH, Moon JH, Ku CR, et al. (2018) Postoperative Gamma Knife Radiosurgery for Cavernous Sinus-Invading Growth Hormone-Secreting Pituitary Adenomas. World Neurosurg 110: e534-e545.

32. Forster N, Warnick R, Takiar V, Pater L, Breneman J (2018) Debulking surgery of pituitary adenoma as a strategy to facilitate definitive stereotactic radiosurgery. J Neurooncol 138(2): 335-340.

33. Sandström H, Chung C, Jokura H, Torrens M, Jaffray D, et al. (2016) Assessment of organs-at-risk contouring practices in radiosurgery institutions around the world - The first initiative of the OAR Standardization Working Group. Radiother Oncol 121(2): 180-186.

34. Sandström H, Jokura H, Chung C, Toma-Dasu I (2018) Multiinstitutional study of the variability in target delineation for six targets commonly treated with radiosurgery. Acta Oncol 57(11): 1515-1520.

35. Yamazaki H, Shiomi H, Tsubokura T, Kodani N, Nishimura T, et al. (2011) Quantitative assessment of inter-observer variability in target volume delineation on stereotactic radiotherapy treatment for pituitary adenoma and meningioma near optic tract. Radiat Oncol 6: 10.

\section{Your next submission with Juniper Publishers will reach you the below assets}

- Quality Editorial service

- Swift Peer Review

- Reprints availability

- E-prints Service

- Manuscript Podcast for convenient understanding

- Global attainment for your research

- Manuscript accessibility in different formats ( Pdf, E-pub, Full Text, Audio)

- Unceasing customer service

Track the below URL for one-step submission https://juniperpublishers.com/online-submission.php 